UDC: 159.955 .4

DOI: https://doi.org/10.24195/2414-4665-2017-7-16

\author{
Svitlana Tsymbal, \\ Ph.D. (Psychology), associate professor, \\ National University of Life and Environmental Sciences of Ukraine
}

\title{
OVERCOMING LANGUAGE ANXIETY AMONG THE ENGLISH LANGUAGE LEARNERS: PSYCHO-PEDAGOGICAL ASPECT
}

Foreign language anxiety, the feeling of tension and apprehension specifically associated with learning a foreign language is considered to be the major factor encountered by language learners around the world. The consideration of language anxiety in the modern English classroom is highly significant to help learners boost their confidence and develop their communication skills in the target language. The current study addresses the following research questions: 1. What factors may cause the anxiety that university students encounter in the process of learning English? 2. What psychological and pedagogical strategies in reducing the language anxiety among English language learners to cope with the language anxiety can be utilized? The research is of qualitative and descriptive type. A survey questionnaire (by Horwitz et al.) was suggested to 86 students of National University of Life and Environmental Sciences of Ukraine, Kyiv. The findings of this study clearly indicate that in spite of the use of modern communicative approaches and techniques by university teachers, the problem of English language anxiety still persists among the students. Teachers should do their best to reduce anxiety in their students by creating an attractive, warm atmosphere inside the classrooms and increasing students' motivation in learning English. They should help their students to cope with negative attitudes and unpleasant feelings towards learning English. Furthermore, they should build students' self-confidence by using positive reinforcement, encouragements. Coping strategies for foreign language anxiety may include those helping the students learn to deal with the context provoking anxiety and those making the learning context less stressful. In order to reduce the language anxiety, special trainings, activities and sessions should be used for language learners such as direct discussing students' anxieties, cooperative learning activities, progressive relaxation, deep breathing, meditation, soothing music and humor, encouraging statements as well.

Keywords: foreign language anxiety, English as a second language, coping strategies

\section{Introduction}

Worldwide expansion of English has increased the necessity to acquire strong English language communication skills which is now imperative in every branch of higher education. The demand placed on international students to become proficient in the English language can negatively affect language learning and cause students to experience stress, nervousness, and anxiety. Among psychologists, educators and researchers, anxiety has been found to interfere with many types of learning and to be one of the most highly researched variables in psychology and education. In the field of English as a second language (ESL) teaching the effects of language anxiety on students has been especially widely studied. Foreign language anxiety (FLA) is a basic human emotion that may be brought on by different situational factors or as a combination of other types of anxiety (fear, stress, threats, dangers, unexpected psychological causes) that relate to language learning [3, p. 128]. Many studies show that FLA is a major factor encountered by ESL learners around the world. Anxiety arising while learning a foreign language in classroom situations was defined by MacIntyre and Gardner as "the feeling of tension and apprehension specifically associated with second language contexts, including speaking, listening and learning". Horwitz, Horwitz and Cope [3, p. 127] state that foreign language anxiety is "a distinct complex of self-perception, feelings and behaviors related to classroom learning language process". Even good learners of English often ex- perience "mental block" and increased anxiety when they have to talk in front of classmates. Consideration of language anxiety in the modern ESL classroom is highly significant to help learners boost their confidence and develop their communication skills in the target language. The current study intends to address the following research questions:

1. What causes might contribute to the anxiety that university students encounter in relation to learning English?

2. What psychological and pedagogical strategies in reducing the language anxiety among ESL learners to cope with the language anxiety can be utilized?

\section{Research methods}

As to methodology, our research is qualitative and descriptive in its nature. A survey questionnaire (Horwitz et al. Foreign Language Classroom Anxiety Scale [FLCAS]) was administered to 86 students of National University of Life and Environmental Sciences of Ukraine, Kyiv.

\section{Research Results and their Discussion}

In psychological literature, anxiety is defined as a psychological state of apprehension, a vague fear that is only indirectly associated with an object [2]. McIntyre and Gardner describe this phenomenon as a subjective feeling of tension, apprehension, nervousness, and worry associated with an arousal of the automatic nervous system [5]. Learning a foreign language is a big challenge as it requires much effort, time and energy. There are many variables which affect language learning such as learning 
styles, motivation, cultural background, emotional factors, etc. One of the most vital affective factors that may impede language learning is foreign language anxiety. The concept of foreign language anxiety is interpreted as the "apprehension experienced when a situation requires the use of a second language with which the individual is not fully proficient. It is, therefore, seen as a stable personality trait referring to the propensity for an individual to react in a nervous manner when speaking, listening, reading, or writing in the second language" $[5$, p. 5].

To reduce the negative impact of foreign language anxiety on ESL learners, it is necessary to determine its causes to understand the nature of anxiety, and to help English teachers find effective strategies of reducing this phenomenon in ESL classrooms. Horwitz and his colleagues state that foreign language anxiety can be related to communication apprehension (the fear of communicating with other people), test anxiety (fear of exams, quizzes, and other activities used to evaluate one's competence) and fear of negative evaluation (the worry about how others view the speaker) [3]. Moreover, Young outlined a number of reasons that may cause foreign language anxiety such as low self-esteem, competitiveness, self-perceived low level of ability, communication apprehension, lack of group membership and attitudes and beliefs about language learning [9]. Also, institutional anxiety can be added to the list of classroom activities that may produce anxiety. These may include: (a) spontaneous role playing; (b) speaking in front of the class; (c) oral presentations and report; and (d) writing tasks on the board [7].

In our study, we used a questionnaire "Foreign Language Classroom Anxiety Scale" (FLCAS) developed by Howitz et al [3] which is a 33-item, 5-point Likert-scale instrument ranged from "strongly disagree to strongly agree" measuring students' language anxiety. The FLCAS was suggested to the first year students during their scheduled English language class at the end of the autumn semester. The items presented are reflective of communication apprehension, test-anxiety, and fear of negative evaluation in the foreign language classroom. Responses to all FLCAS items are reported in Table 1. All percentages refer to the number of students who agreed or strongly agreed (or disagreed and strongly disagreed) with statements indicative of foreign language anxiety.

Table 1.

Percentages of Students Selecting Each ITEM of FLCAS

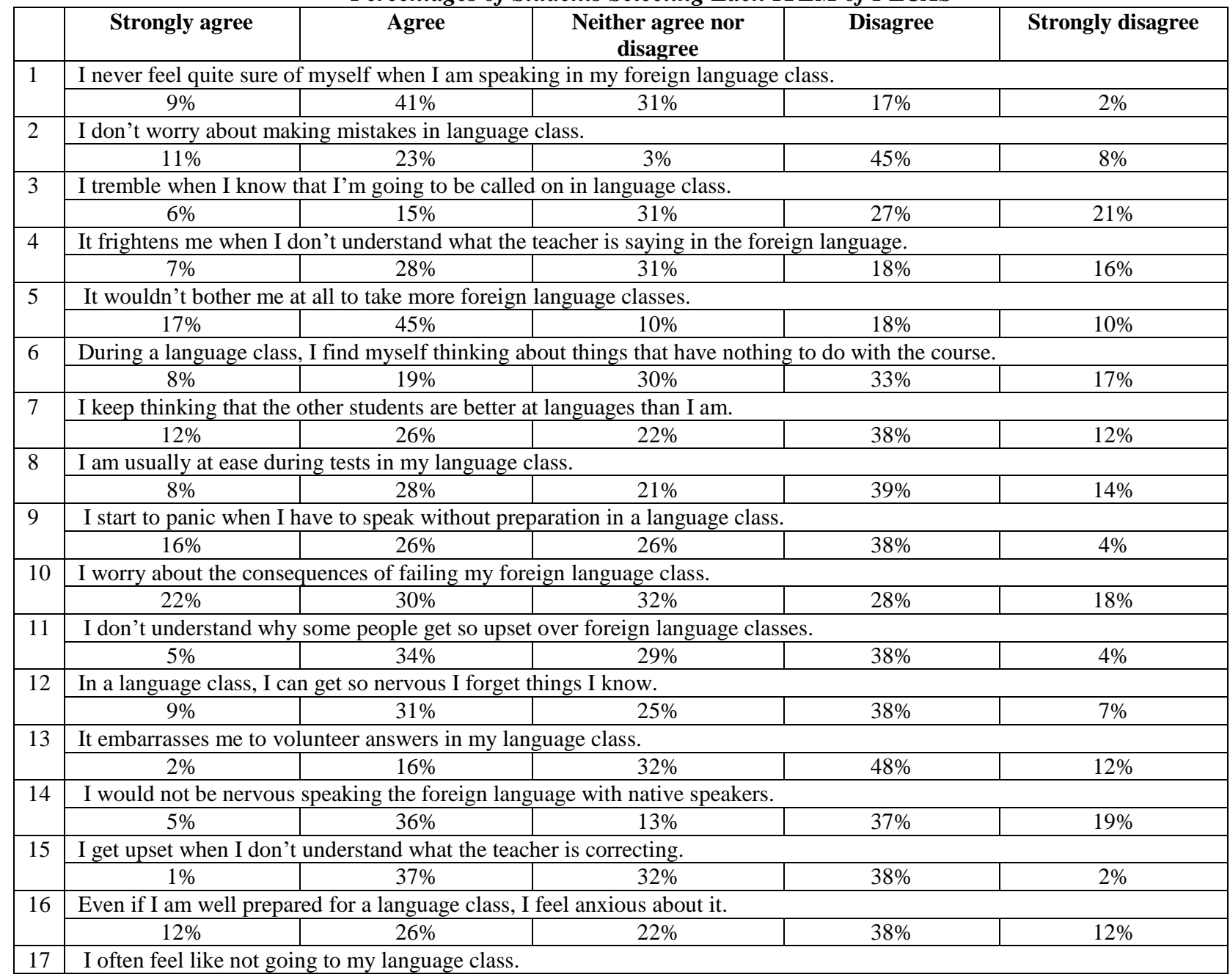




\begin{tabular}{|c|c|c|c|c|c|}
\hline & Strongly agree & Agree & $\begin{array}{c}\text { Neither agree nor } \\
\text { disagree }\end{array}$ & Disagree & Strongly disagree \\
\hline & $11 \%$ & $25 \%$ & $24 \%$ & $37 \%$ & $13 \%$ \\
\hline \multirow[t]{2}{*}{18} & \multicolumn{5}{|c|}{ I feel confident when I speak in a foreign language class. } \\
\hline & $2 \%$ & $27 \%$ & $31 \%$ & $46 \%$ & $4 \%$ \\
\hline \multirow[t]{2}{*}{19} & \multicolumn{5}{|c|}{ I am afraid that my language teacher is ready to correct every mistake I make. } \\
\hline & $2 \%$ & $36 \%$ & $22 \%$ & $36 \%$ & $14 \%$ \\
\hline \multirow[t]{2}{*}{20} & \multicolumn{5}{|c|}{ I can feel my heart pounding when I'm going to be called on in language class. } \\
\hline & $5 \%$ & $25 \%$ & $29 \%$ & $39 \%$ & $12 \%$ \\
\hline \multirow[t]{2}{*}{21} & \multicolumn{5}{|c|}{ The more I study for a language test, the more confused I get. } \\
\hline & $2 \%$ & $16 \%$ & $22 \%$ & $48 \%$ & $22 \%$ \\
\hline \multirow[t]{2}{*}{22} & \multicolumn{5}{|c|}{ I don't feel pressure to prepare very well for a language class. } \\
\hline & $4 \%$ & $25 \%$ & $26 \%$ & $42 \%$ & $23 \%$ \\
\hline \multirow[t]{2}{*}{23} & \multicolumn{5}{|c|}{ I always feel that other students speak the foreign language better than I do. } \\
\hline & $12 \%$ & $20 \%$ & $33 \%$ & $32 \%$ & $13 \%$ \\
\hline \multirow[t]{2}{*}{24} & \multicolumn{5}{|c|}{ I feel very self-conscious about speaking the foreign language in front of other students. } \\
\hline & $2 \%$ & $24 \%$ & $26 \%$ & $48 \%$ & $10 \%$ \\
\hline \multirow[t]{2}{*}{25} & \multicolumn{5}{|c|}{ Language class is moving so quickly I worry about getting left behind. } \\
\hline & $12 \%$ & $46 \%$ & $22 \%$ & $18 \%$ & $12 \%$ \\
\hline \multirow[t]{2}{*}{26} & \multicolumn{5}{|c|}{ I feel more tense and nervous in my language class than in my other classes. } \\
\hline & $13 \%$ & $27 \%$ & $32 \%$ & $15 \%$ & $13 \%$ \\
\hline \multirow[t]{2}{*}{27} & \multicolumn{5}{|c|}{ I get nervous and confused when I am speaking in my language class. } \\
\hline & $6 \%$ & $32 \%$ & $35 \%$ & $33 \%$ & $4 \%$ \\
\hline \multirow[t]{2}{*}{28} & \multicolumn{5}{|c|}{ When I'm on my way to a language class, I feel very sure and relaxed. } \\
\hline & $2 \%$ & $26 \%$ & $42 \%$ & $35 \%$ & $5 \%$ \\
\hline \multirow[t]{2}{*}{29} & \multicolumn{5}{|c|}{ I get nervous when I don't understand every word the language teacher says. } \\
\hline & $2 \%$ & $5 \%$ & $38 \%$ & $48 \%$ & $17 \%$ \\
\hline \multirow[t]{2}{*}{30} & \multicolumn{5}{|c|}{ I feel overwhelmed by the number of rules you have to learn to speak a foreign language. } \\
\hline & $10 \%$ & $23 \%$ & $35 \%$ & $38 \%$ & $4 \%$ \\
\hline \multirow[t]{2}{*}{31} & \multicolumn{5}{|c|}{ I am afraid that the other students will laugh at me when I speak the foreign language. } \\
\hline & $3 \%$ & $6 \%$ & $44 \%$ & $30 \%$ & $17 \%$ \\
\hline \multirow[t]{2}{*}{32} & I would probably fe & e aroun & akers of the foreign 1 & & \\
\hline & $5 \%$ & $29 \%$ & $22 \%$ & $33 \%$ & $11 \%$ \\
\hline 33 & I get nervous whe & teacher & which I haven't $\mathrm{p}$ & advance. & \\
\hline & $5 \%$ & $37 \%$ & $33 \%$ & $23 \%$ & $2 \%$ \\
\hline
\end{tabular}

Our findings suggest that considerable foreign language anxiety is experienced by the students in response to many aspects of English language learning. A majority of the statements reflective of foreign language anxiety (nineteen of thirty-three items) were supported by a third or more of the students surveyed, and seven statements were supported by over half the students. Although at this point we can only speculate as to how many people experience severe reactions to foreign language learning, these results imply that anxious students are common in foreign language classrooms (at least in their first year at the university level).

The second research question addresses the strategies that can be used by teachers and learners to cope with the language anxiety. In general, educators have two options when dealing with anxious students: 1) they can help them learn to cope with the existing anxiety provoking context; or 2) they can make the learning context less stressful.

Based on the survey, we have identified the following groups and anxiety provoking contexts:

1. Anxiety related to the English classroom (participating in class without being prepared; anxiety about failing the exams, completing assignments; passing the course; class assignments, etc.);
2. Self-perception (anxiety related to one's own English proficiency, etc.);

3. General anxiety exacerbated in English contexts (troubles in expressing ideas; interactions with more fluent classmates; fear of making a mistake, fear of evaluation, etc.);

4. Anxiety related to English communication (speaking English in front of the class; difficulty in following teachers' (and classmates') talk; difficulty in making one's point in English, etc.).

Coping strategies for FLA may include the following:

- participate in class with a positive attitude;

- address difficulties actively;

- distance oneself from troubles;

- prepare for speaking English in advance;

- make greater efforts to endure one's anxiety;

- ask for help from classmates (and teachers);

- try to get through the difficulty;

- ignore the difficulty;

- try to use English within one's limited language proficiency;

- try to deal with the trouble constructively;

- do an imagery rehearsal before the presentation;

- say “Things will work out!” silently to oneself; 

tions;

- try not to worry about making mistakes in presenta-

- review completed assignment several times.

To make the learning context less stressful, teachers should:

- create a friendly and learning supportive environment in language classrooms;

- try to encourage their students whenever they make mistakes in language classrooms;

- use gentle or non-threatening methods of errors correction;

- always be ready to offer words of encouragement;

- arrange the discussion of students' areas of interest in language classrooms;

- plan their lessons from the students' perspective (student-centered lessons);

- discuss language anxiety openly with their students.

Also, special trainings, activities and sessions in order to reduce the language anxiety should be used for ESL learners. The role of such techniques in reducing the language anxiety among ESL learners is immense. One of them is cooperative learning which involves forming small groups of students of varying background and ability levels, who work together to complete various language tasks. This method creates a sense of community in the classroom and students feel more relaxed. According to Kagan \& Kagan [4], some of the cooperative learning activities may include: "Round Robin", "Timed Pair Share", "Inside-Outside Circle", "Find Someone Who", "Pairs Compare", "Find-the-Fiction".

Language teachers can also teach students how to use affective strategies to reduce their anxiety [6]. Students can use the techniques of progressive relaxation, deep breathing, meditation and soothing music to put themselves in a positive mood. To encourage relaxation, teachers can also use funny videos, jokes, role-plays, games and other fun activities to stimulate laughter in their classrooms and make students feel more at ease.

Teaching students to encourage themselves is another affective strategy that can help to reduce anxiety levels [6]. It is highly recommended that students be taught to make regular positive statements about themselves and their progress in language learning. Some positive statements might be as follows:

\section{REFERENCES}

1. Gardner, R., \& MacIntyre, P. (1993). A student's contribution to second language learning. Part II: affect variables. Language Teaching, 26, 1-11 [in English].

2. Hilgard, E. R., Atkinson, R. C., \& Atkinson, R. L. (1971). Introduction to psychology (5th ed.). New York: Harcourt [in English].

3. Horwitz, E. K., Horwitz, M. B., \& Cope, J. A. (1986). Foreign Language Classroom Anxiety, The Modern Language Journal, Vol. (2), (pp. 125-132) [in English].

4. Kagan, S., \& Kagan, M. (2009). Kagan cooperative learning. San Clemente, CA: Kagan Publishing [in English].
I understand a lot more of what is said in the target language.

It's okay if I make mistakes because they help me learn.

The more I practice speaking, the better my pronunciation becomes.

I took a risk today and tried using a new phrase.

I had a successful conversation today in the target language.

Students should also be encouraged to reward themselves when they achieve a personal goal [6]. Setting goals and rewarding oneself can be a good way of improving attitude and motivation in regards to the language learning process. In addition, language teachers may take a more direct approach towards reducing students' anxieties: discussing students' anxieties with them and incorporating specific strategies and activities aimed at creating a low anxiety classroom environment.

\section{Conclusions}

The findings of this study clearly indicate that in spite of the use of modern communicative approaches and techniques by university teachers, the problem of English language anxiety still persists among the students. It still needs to be researched in more detailed way. The students' lack of confidence, their inability to participate in the classroom discussions, their low self-esteem, speaking apprehension, their nervousness and a feeling of getting behind are, however, also some of the primary factors that do result in language anxiety.

Teachers should play a major role in reducing anxiety in their students by creating an attractive, warm atmosphere inside the classrooms and increasing students' motivation in learning English. They should help their students to cope with negative attitudes and unpleasant feeling towards learning English. Furthermore, they should build students' self-confidence by using positive reinforcement, more encouragements.

Coping strategies for FLA may include those helping the students learn to cope with the existing anxiety provoking context and those making the learning context less stressful. In order to reduce the language anxiety, special trainings, activities and sessions should be used for ESL learners such as direct discussing students' anxieties, cooperative learning activities, progressive relaxation, deep breathing, meditation, soothing music and humor, encouraging statements as well.

5. MacIntyre, P.D., \& Gardner, R.C. (1994). The subtle effects of language anxiety on cognitive processing in the second language. Language Learning, 44, pp. 283305 [in English].

6. Oxford, R. (1990). Applying indirect strategies to the four language skills. In Language learning strategies: What every teacher should know (pp. 151-191). Boston, MA: Heinle and Heinle [in English].

7. Oxford, R.L. (1999). Strategy research compendium: Language learning strategies in the context of auton- 
omy. New York: Teachers College, Columbia University/ Tuscaloosa, AL: University of Alabama [in English].

8. Young, D.J. (1990). An investigation of students' perspectives on anxiety and speaking. Foreign Language Annals, 23(6), 539-553 [in English].

\section{ЛІТЕРАТУРА}

1. Gardner R. A student's contribution to second language learning. Part II: affect variables / R. Gardner, P. MacIntyre // Language Teaching. - 1993. - № 26. - P. 1-11. [In English]

2. Hilgard E.R. Introduction to psychology (5th ed.) / E.R. Hilgard, R.C. Atkinson, R.L. Atkinson. - New York: Harcourt, 1971. [In English]

3. Horwitz E.K. Foreign Language Classroom Anxiety / E.K. Horwitz, M.B. Horwitz, J.A. Cope // The Modern Language Journal. - 1986. - Vol. 2. - P. 125-132. [In English]

4. Kagan S. Kagan cooperative learning / S. Kagan, M. Kagan. - San Clemente, CA: Kagan Publishing, 2009.

5. MacIntyre P.D. The subtle effects of language anxiety on cognitive processing in the second language / P.D. MacIntyre, R.C. Gardner // Language Learning. 1994. - №44. - P. 283-305
9. Young, D.J. (1994). New directions in language anxiety research. In C.A. Klee (Ed.). Faces in a crowd: The individual learner in multisection courses. MA: Heinle \& Heinle [in English].

6. Oxford R. Applying indirect strategies to the four language skills / R. Oxford // Language learning strategies: What every teacher should know. - Boston, MA: Heinle and Heinle, 1990. - P. 151-191.

7. Oxford R.L. Strategy research compendium: Language learning strategies in the context of autonomy / R.L. Oxford. - New York: Teachers College, Columbia University/ Tuscaloosa, AL: University of Alabama, 1999.

8. Young D.J. An investigation of students' perspectives on anxiety and speaking / D.J. Young // Foreign Language Annals. - 1990. - №23(6). - P. 539-553.

9. Young D.J. New directions in language anxiety research / Young D.J. // Faces in a crowd: The individual learner in multisection courses. - MA: Heinle \& Heinle, 1994.

Світлана Володимирівна Цимбал, кандидат психологічних наук, доцент кафедри англійської мови для технічних та агробіологічних спеціальностей, Національний університет біоресурсів і природокористування Украӥни, вул. Героїв Оборони, 15, м. Київ, Украӥна

\section{ПОДОЛАННЯ МОВНОЇ ТРИВОЖНОСТІ В ПРОЦЕСІ ВИВЧЕННЯ АНГЛІЙСЬКОЇ МОВИ: ПСИХОЛОГО-ПЕДАГОГІЧНИЙ АСПЕКТ}

Тривожність, яка виникає в процесі вивчення іноземної мови, відчуття напруженості та занепокоєння вважаються основним бар'єром, з яким зіштовхуються люди в усьому світі на шляху опанування іноземної мови. Вивчення явища іншомовної тривожності в контексті сучасної іншомовної освіти є дуже важливим, щоб допомогти студентам підвищити їхню впевненість та розвинути комунікативні навички у цільовій мові. У статті розглядаються такі дослідницькі питання: 1. Які причини можуть викликати тривожність студентів вишів стосовно вивчення англійської мови? 2. Які психологічні та педагогічні стратегії зменшення мовної тривожності серед студентів, що вивчають англійську мову, можна використовувати? Що стосується методології, то сучасне дослідження за своїм характером є якісним та описовим. В опитуванні (анкета за Horwitz et al.) взяли участь 86 студентів, які навчаються в Національному університеті біоресурсів і природокористування України, м. Київ. Результати цього дослідження чітко вказують на те, що, незважаючи на використання сучасних комунікативних підходів та методів викладачами університетів, студенти все ж відчувають тривожність у процесі вивчення англійської мови. Викладачі повинні відігравати важливу роль у зменшенні тривожності серед своїх студентів, створюючи теплу атмосферу в аудиторії та підвищуючи мотивацію студентів до вивчення англійської мови. Вони повинні допомогти своїм студентам впоратись 3 негативними настроями та неприємними відчуттями щодо вивчення англійської мови. Крім того, викладачі повинні формувати впевненість у студентів, позитивно їх налаштовувати та використовувати щобільше заохочень. Стратегії подолання іншомовної тривожності можуть включати ті, що допомагають студентам навчитися справлятися з контекстом, який провокує тривожність, й ті, що створюють менше стресу в процесі навчання. Для зменшення мовної тривожності у студентів, які вивчають іноземну мову, слід використовувати спеціальні тренінги, заняття, такі як пряме обговорення проблеми тривожності, спільну навчальну діяльність, техніки поступового розслаблення, глибокого дихання, медитації, заспокійливу музику та гумор, а також заохочувальні висловлювання.

Ключові слова: іншомовна тривожність, англійська мова як друга мова, стратегії подолання іншомовної тривожності.

Submitted on June, 14, 2017

Reviewed by Doctor of Philology, prof. V. Shynkaruk 